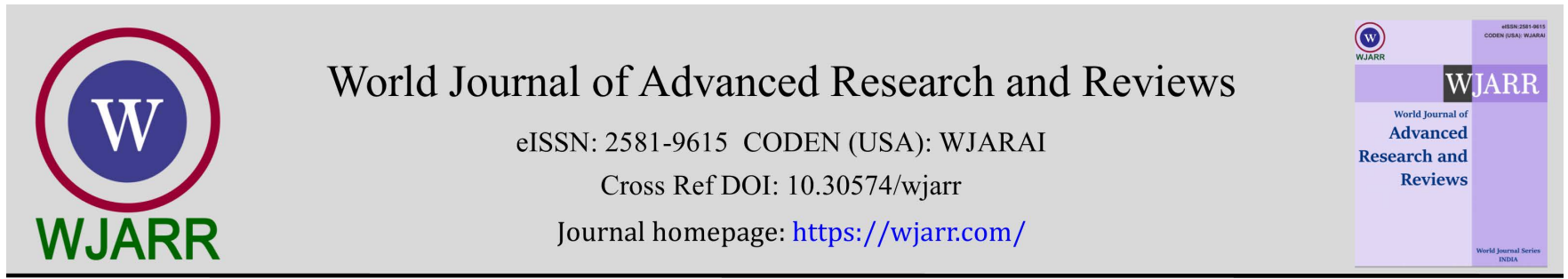

(RESEARCh ARTICLE)

Check for updates

\title{
Instagram campaign about COVID-19 vaccine, variant of COVID-19 virus, use of mask, and daily activities in a pandemic situation
}

Muhammad Anas Farobi 1, Anisa Putri Amanda 1, Nadyalifa Tania Putri 1, Dewi Ratna Sari 2, *, Bella Salsabila 1, Dhia Farhan Taufik ${ }^{1}$, Hammam Izza Rofiqi ${ }^{1}$, Daniel Jonathan Mangapul Siagian ${ }^{1}$, Marsa Safira ${ }^{1}$ and Aisha Maharani Aliski ${ }^{1}$

\author{
${ }^{1}$ Medical Program, Faculty of Medicine, Universitas Airlangga, Surabaya, East Java, Indonesia. \\ 2 Department of Anatomy, Histology, and Pharmacology, Faculty of Medicine, Universitas Airlangga, Surabaya, East Java, \\ Indonesia.
}

World Journal of Advanced Research and Reviews, 2022, 13(01), 672-678

Publication history: Received on 10 December 2021; revised on 12 January 2022; accepted on 14 January 2022

Article DOI: https://doi.org/10.30574/wjarr.2022.13.1.0052

\begin{abstract}
Since the establishment of COVID-19 as a global pandemic by WHO in 2020, cases have increased worldwide, especially in Indonesia. Over time, the vaccination program has been implemented. Still, the public's lack of vigilance, particularly regarding the use of double masks and adaptation to the current pandemic situation, is causing an increase in cases, especially in June-July 2021. Therefore, Instagram for educational campaigns can deliver more interactive material using existing features. This study aimed to know Instagram users' knowledge level about COVID-19 by giving quizzes with answer choices. As a result, Instagram users who became our campaign participants have a knowledge average above $50 \%$ for all the four campaign themes, with the lowest average for the variant theme and the highest average for the vaccine theme. In conclusion, Instagram users who became our participants have enough knowledge of campaign materials.
\end{abstract}

Keywords: Virus; COVID-19; An educational campaign; Vaccine; Mask; Daily activities

\section{Introduction}

Coronavirus disease 2019 or COVID-19 is an infectious disease with a high spread caused by Severe Acute Respiratory Syndrome Coronavirus 2 (SARS-CoV-2). This virus was first reported in December 2019 in Wuhan, China. The spread of SARS-CoV-2 was speedy worldwide in a short period. Since March 11, 2020, the World Health Organization (WHO) has declared this virus a global pandemic. The disease spreads through droplets when an infected person coughs, sneezes, talks, or breathes. Droplets containing this virus can stick to the surface of objects, and if these contaminated objects are touched by hands and touch parts of the face such as eyes, nose, or mouth, the spread of the virus can also occur $[1,2]$.

With the implementation of the COVID-19 vaccination in Indonesia, various kinds of information about vaccines circulated uncontrollably, including the many conspiracies that emerged about vaccines. The lack of understanding about vaccines has led to the emergence of groups of pros and cons with vaccines. The group with low understanding will be against and more believe in vaccine conspiracies and refuse to know the truth [3]. In addition, the emergence of a new variant of the SARS-CoV-2 virus, namely the delta variant with its distinctive characteristics, also shocked the public and made information about virus variants widespread. The increasing number of cases has also led to new rules, namely the use of double masks [4]. The stipulation of this new rule had raised questions and public commotion.

\footnotetext{
* Corresponding author: Dewi Ratna Sari

Department of Anatomy, Histology, and Pharmacology, Faculty of Medicine, Universitas Airlangga, Surabaya, East Java, Indonesia.

Copyright (C) 2022 Author(s) retain the copyright of this article. This article is published under the terms of the Creative Commons Attribution Liscense 4.0
} 
However, the increasing number of cases in the last two months is not accompanied by increased self-awareness in the community. Data shows that there are 20 provinces with average compliance of wearing masks and maintaining distance below $85 \%$ [5]. In the current situation, the community has an essential role in stopping the spread of COVID19. Looking back at the differences in conditions before and after the pandemic, preventing and controlling the community is necessary. Those actions can be done by preventing individual transmission and providing health protection for the community [6].

Social media, especially Instagram, can conduct educational campaigns for young people because around 85-95\% of students use social media actively. Social media can also become a bridge between education and entertainment to become a more exciting learning method for students [7]. Although not designed as an educational or learning tool, social media, especially Instagram, can be a powerful tool to encourage participation and communication in an educational context. The delivery of education through Instagram is considered to fulfill alternative learning methods other than classical learning methods such as lectures or school. Instagram uses the concept of sharing photos and videos in its application. This concept is also considered effective in delivering material because users can visualize the material presented [8]. In this pandemic era, Instagram has experienced an increase in the number of users, and this is because Instagram has become a connecting platform for family, friends, and colleagues [9]. In addition, Instagram is also considered by most people as a medium to seek and find all information, especially those related to COVID-19 [10]. Therefore, easy access to information through social media is an alternative to provide education to the broader community during the pandemic. This activity aims to provide education regarding vaccines, variants of COVID-19, the use of masks, and adaptation to life during the pandemic through an Instagram campaign.

\section{Material and methods}

The implementation of community service activities was carried out with social media campaigns through the Instagram story feature. The material presented in the campaign consists of 4 topics, namely the COVID-19 vaccine, the COVID-19 variant, the use of masks, and daily activities in the new normal era. Each topic was presented in one day, except for the variant topic, which was presented for two days, namely July 14 and 15, 2021. The campaign was conducted through our group's Instagram account (@weave.project) and 9 Instagram accounts of each member of group 23 Community Service Program FK UNAIR 2021 COVID module, so the total accounts used are 10 Instagram accounts.

This activity was carried out for five days, and every day the campaign was divided into three sessions. The first session gave questions with answer choices, the second session gave answers and explanations of questions in the first session, and the last session is a free question column to be filled in by Instagram users. Each topic had three questions that had been asked to Instagram users through the story feature, except for the topic of the COVID-19 virus variant, which had six questions. The questions given were multiple choices consisting of 4 options, so Instagram users simply choose one of the correct answers and there was also one question as an open-ended question in the variant topic. The data was obtained in the number of participants who answered questions on Instagram stories, the number of participants who answered the questions correctly, and the percentage of participants who answered correctly compared to the total participants.

\section{Results and discussion}

Table 1 displays data on the number of participants, the number of participants who answered correctly, and the percentage of participants who answered correctly for each question.

Table 1 Instagram campaign results data based on question items

\begin{tabular}{|c|c|c|c|}
\hline Topic & Questions & $\begin{array}{l}\text { Number of } \\
\text { Participants }\end{array}$ & $\begin{array}{l}\text { Number of Participants } \\
\text { with Correct Answer }\end{array}$ \\
\hline \multirow[t]{2}{*}{ Vaccine } & $\begin{array}{l}\text { 1. If a person receives a vaccine, what will be formed in } \\
\text { the body? } \\
\text { A. Antigen } \\
\text { B. Antibodies }\end{array}$ & 71 & 68 (95.77\%) \\
\hline & $\begin{array}{l}\text { 2. What are the essential ingredients for making the } \\
\text { COVID-19 vaccine used in Indonesia? }\end{array}$ & 81 & $41(50.62 \%)$ \\
\hline
\end{tabular}




\begin{tabular}{|c|c|c|c|}
\hline & $\begin{array}{l}\text { A. Inactivated virus } \\
\text { B. Viral vector } \\
\text { C. mRNA } \\
\text { D. All answers are correct }\end{array}$ & & \\
\hline & $\begin{array}{l}\text { 3. Who should not receive the COVID-19 vaccine? } \\
\text { A. People with fever }>37.5^{\circ} \mathrm{C} \\
\text { B. People who have asthma } \\
\text { C. Children aged } 12-17 \text { years }\end{array}$ & 70 & 52 (74.29\%) \\
\hline \multirow{6}{*}{ Variants } & $\begin{array}{l}\text { 1. Difference between variant of interest and variant of } \\
\text { concern }\end{array}$ & 112 & $42(37.50 \%)$ \\
\hline & $\begin{array}{l}\text { 2. Which variants are included in the VOC group? } \\
\text { A. Theta } \\
\text { B. Lambda } \\
\text { C. Gamma } \\
\text { D. Kappa }\end{array}$ & 128 & 49 (38.28\%) \\
\hline & $\begin{array}{l}\text { 3. Which variant has not been detected in Indonesia? } \\
\text { A. Alpha } \\
\text { B. Beta } \\
\text { C. Delta } \\
\text { D. Gamma }\end{array}$ & 120 & $74(61.67 \%)$ \\
\hline & $\begin{array}{l}\text { 4. Which variant caused the explosion of cases in July } \\
2021 \text { ? } \\
\text { A. Delta } \\
\text { B. Alpha } \\
\text { C. Iota } \\
\text { D. Kappa }\end{array}$ & 88 & 76 (86.36\%) \\
\hline & $\begin{array}{l}\text { 5. Is it true that all Variants of Interest have entered } \\
\text { Indonesia? } \\
\text { A. True } \\
\text { B. False }\end{array}$ & 86 & $28(32.56 \%)$ \\
\hline & $\begin{array}{l}\text { 6. What type of vaccine proven to reduce risk of infection } \\
\text { due to the delta variant of the SARS-CoV-2 virus? } \\
\text { A. Moderna } \\
\text { B. Sinovac } \\
\text { C. Pfizer } \\
\text { D. All answers are correct }\end{array}$ & 84 & $40(47.62 \%)$ \\
\hline \multirow[b]{2}{*}{ Mask } & $\begin{array}{l}\text { 1. How long is the duration of use for cloth masks? } \\
\text { A. } 4 \text { Hours } \\
\text { B. } 8 \text { Hours } \\
\text { C. } 12 \text { Hours }\end{array}$ & 193 & $130(67.36 \%)$ \\
\hline & $\begin{array}{l}\text { 2. Below is the recommended way when using the double } \\
\text { mask technique: } \\
\text { A. Cloth mask with a cloth mask } \\
\text { B. Medical mask with a cloth mask } \\
\text { C. Medical mask with medical mask }\end{array}$ & 214 & $182(85.05 \%)$ \\
\hline
\end{tabular}




\begin{tabular}{|c|c|c|c|}
\hline & $\begin{array}{l}\text { 3. T/F when taking off the mask, we have to pull the } \\
\text { outside of the mask } \\
\text { A. True } \\
\text { B. False }\end{array}$ & 210 & 97 (46.19\%) \\
\hline \multirow{3}{*}{ Daily } & $\begin{array}{l}\text { 1. Which of the following activities has the lowest risk of } \\
\text { being infected with the COVID- } 19 \text { virus? } \\
\text { A. Watching cinema with " } 2 \text { seats away" distance from } \\
\text { one to another } \\
\text { B. Walking in a park that is not crowded } \\
\text { C. Walking in a mall }\end{array}$ & 173 & $139(80.35 \%)$ \\
\hline & $\begin{array}{l}\text { 2. What is the recommended minimum distance in } \\
\text { Indonesia to reduce the risk of transmitting COVID-19? } \\
\text { A. } 1 \text { meter } \\
\text { B. meters }\end{array}$ & 174 & 87 (50.00\%) \\
\hline & $\begin{array}{l}\text { 3. Below are factors that need to be considered so that } \\
\text { activities carried out during the pandemic can be safer, } \\
\text { except? } \\
\text { A. Place } \\
\text { B. Distance } \\
\text { C. Weather }\end{array}$ & 174 & 137 (78.74\%) \\
\hline
\end{tabular}

Nine of the 15 questions had a percentage of participants who answered correctly more than $50 \%$. The question with the highest percentage of participants who answered correctly was question number 1 on vaccines with a percentage of $95.77 \%$, while the question with the lowest percentage of participants who answered correctly was question number 5 on the topic of variants with a percentage of $32.56 \%$. The number of Instagram users who answered each of the questions on each topic varies on each account used, so the participants who answered each Instagram story need to be summed and averaged. The average number of participants from each topic is presented in the form of a graph as follows

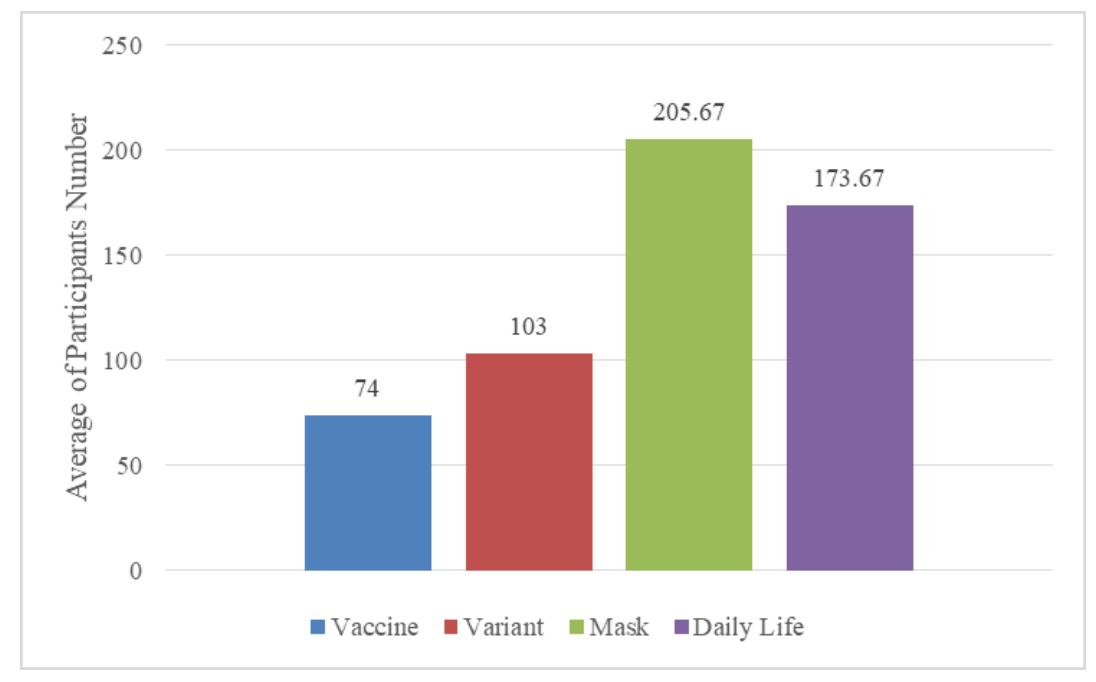

Figure 1 The average of participant's number on each topic

Figure 1 shows that the vaccine topic has the lowest average of participant's number, while the mask topic has the highest average of participant number. This may be due to the vaccine topic campaign that was conducted on Monday, while the mask topic campaign was conducted on Saturday, which was the prime time of the Instagram application [11]. 


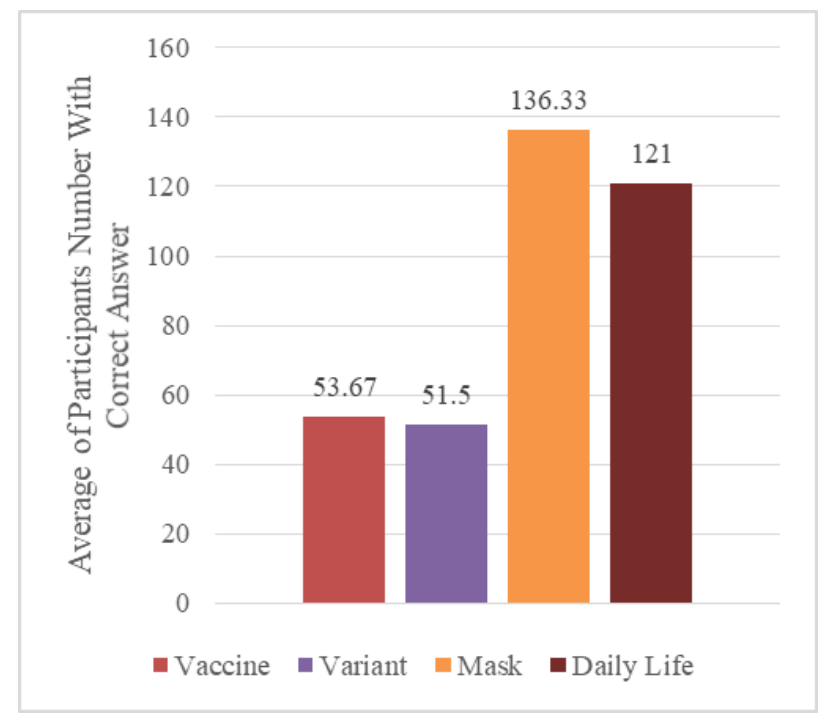

Figure 2 The average of the participant's number with the correct answer in each topic

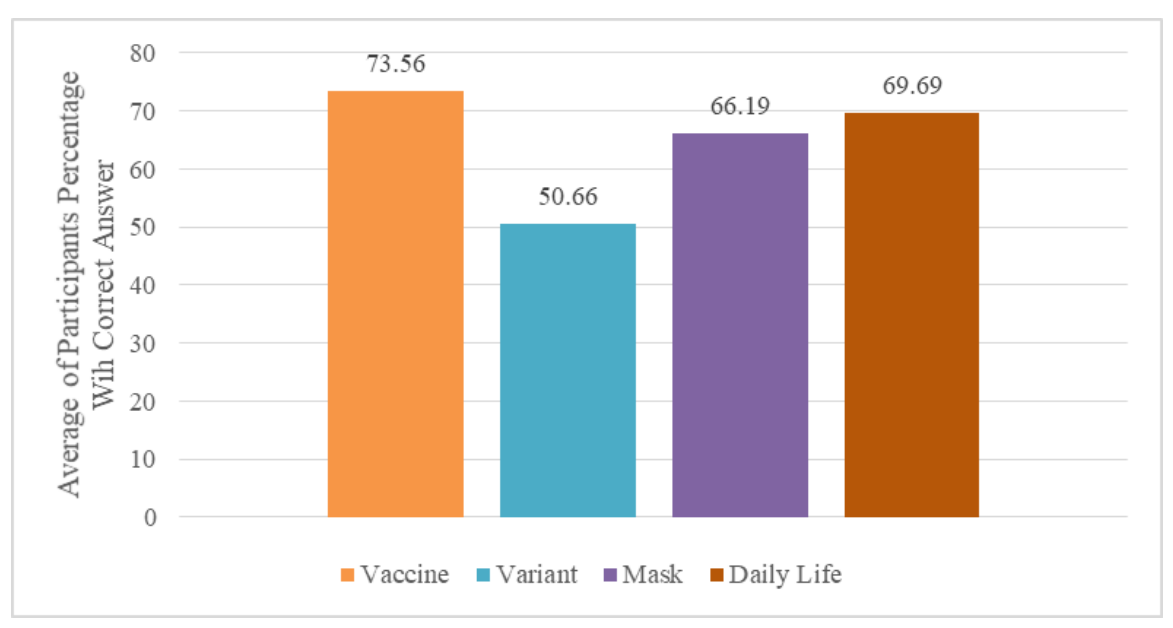

Figure 3 The average of participant's percentage with the correct answer on each topic

Figure 2 shows that the variant topic has the lowest average of participant's number who answered correctly, while the mask topic has the highest average of participant's number who answered correctly. This is due to the number of participants in the variant topic being the fewest participants, and the masks topic was the most participants. Meanwhile, when viewed from the percentage according to Figure 3, it can be seen that the variant topic has the lowest average of participant's percentage who answered correctly, and the vaccine topic has the highest average of participant's percentage who answered correctly. These results indicated that Instagram users were still not aware of the SARS-CoV-2 variant widely spread and already found in Indonesia. The open-ended question on variant topics might contribute to the low average percentage of participants who answered correctly since open-ended questions tend to discourage some of the participants with a low level of literacy or participants that have difficulties expressing their ideas through written form [12]. Research conducted online through several social media in March 2020 also supports our findings that respondents were more concerned about the impact of COVID-19 on the economy, healthcare system, society, changes in daily routines, and losing their jobs rather than the virus itself [13].

Moreover, the mandatory COVID-19 vaccination program through Minister of Health Regulation number 10 , the year 2021, and the implementation of emergency enforcement of restriction on community activities / Pemberlakuan Pembatasan Kegiatan Masyarakat (PPKM) by Minister of Home Affairs Instruction number 5, the year 2021 regarding vaccine requirements for people who want to travel dan activities during the emergency PPKM, increased the public interest in COVID-19 vaccines [14, 15].

In addition, the large amount of information about vaccines from various media and the high activity of the community in seeking vaccine information has made Instagram users gain much knowledge about the COVID-19 vaccine and led to 
a high percentage of participants who answered correctly $[16,17]$. This is in line with the research that was conducted at SMA Negeri 2 plus Panyabungan, a public high school in North Sumatra, which showed that the highest level of knowledge about the symptoms and prevention of COVID-19 was good knowledge level with a total of 126 people (97.7\%) [18]. Studies conducted in Ethiopia also state that most of the participants of the study (68.66\%) have a good level of knowledge regarding COVID-19. Based on this study, reading COVID-19 information through social media and using the source of information daily was reported to have a smaller risk of poor COVID-19 knowledge [19]. Furthermore, the results obtained in this campaign can be used as a basis for determining the following socialization material, it regards the COVID-19 variant with different methods to increase public understanding.

\section{Conclusion}

Social media campaign participants have understood the topic that has been given, with the average percentage of participants who answered correctly on each topic reaching more than 50\%, with the lowest average on the topic of variance and the highest average on the topic of Vaccines. Therefore, selecting topics that follow the community's needs and the right time to implement social media campaigns can maximize results.

\section{Compliance with ethical standards}

\section{Acknowledgments}

Thank you to Faculty of Medicine, Universitas Airlangga for facilitating the COVID-19 Module Community Service Program. Thanks are also conveyed to our supervisors during the COVID-19 Module and also our Instagram followers whom helped us on participating in our study.

\section{Disclosure of conflict of interest}

The authors have no conflicts of interest to declare.

\section{Statement of informed consent}

Informed consent was obtained from all individual participants included in the study.

\section{References}

[1] Cascella M, Rajnik M, Aleem A, Dulebohn SC, Napoli R. Features, Evaluation, and Treatment of Coronavirus (COVID-19). StatPearls Publishing. 2021.

[2] CDC. COVID-19 and Your Health. Centers for Disease Control and Prevention. 2021.

[3] Pivetti M, Melotti G, Bonomo M, Hakoköngäs E. Conspiracy Beliefs and Acceptance of COVID-Vaccine: An Exploratory Study in Italy. Soc Sci. Mar 2021; 10(3): 108.

[4] CDC. Your Guide to Masks. Centers for Disease Control and Prevention. 2021.

[5] Satgas COVID-19, editor. Monitoring Kepatuhan Protokol Kesehatan Tingkat Nasional. 2021.

[6] Kemenkes RI. Pedoman Pencegahan Dan Pengendalian Coronavirus Disease 2019 (COVID-19). Jakarta: Kementerian Kesehatan RI. 2020.

[7] Arceneaux PC, Dinu LF. The social-mediated age of information: Twitter and Instagram as tools for information dissemination in higher education. New Media Soc. Nov 2018; 20(11): 4155-76.

[8] Arslan A. Instagram as an Education Platform for EFL Learners. Turkish Online J Educ Technol. 2019; 18(3): 5469.

[9] Fadilla QY. Tren Konten Instagram Selama Masa Karantina Pandemi COVID-19 di Indonesia. Ultim J Ilmu Komun. Dec 2020; 12(2): 185-205.

[10] Elgaputra RR, Adhi Sakti EY, Widyandri DB, Azhari AR, Renatta C, Rainasya K, et al. Implementasi Sosialisasi COVID-19 dalam Upaya Meningkatkan Kesadaran Masyarakat terhadap Protokol Kesehatan di Kota Jakarta. J Layanan Masy (Journal Public Serv. Nov 2020; 4(2): 423.

[11] Priadana A, Murdiyanto AW. Analisis Waktu Terbaik untuk Menerbitkan Konten di Instagram untuk Menjangkau Audiens. J Penelit Pers dan Komun Pembang. Jun 2020; 24(1): 59-70. 
[12] Connor Desai S, Reimers S. Comparing the Use of Open and Closed Questions for Web-Based Measures of the Continued-Influenced Effect. Behaviour Research Methods. 2018; 51(3): 1426-1440.

[13] Mertens G, Gerritsen L, Duijndam S, Salemink E, Engelhard I. Fear of The Coronavirus (COVID-19): Predictors in an online study conducted in March 2020. Journal of Anxiety Disorders. 2020; 74: 102258.

[14] Menteri Dalam Negeri Republik Indonesia. Instruksi Menteri Dalam Negeri Nomor 15 Tahun 2021 Tentag Pemberlakuan Pembatasan Kegiatan Masyarakat Darurat Corona Virus Disease 2019 di Wilayah Jawa dan Bali. Jakarta. 2021.

[15] Menteri Kesehatan Republik Indonesia. Peraturan Menteri Kesehatan Republik Indonesia Nomor 10 Tahun 2021 Pelaksanaan Vaksinasi Dalam Rangka Penanggulangan Pandemi Coronavirus Disease 2019 (COVID-19). Jakarta. 2021.

[16] Letuna MAN. Instagram sebagai Media Edukasi Vaksin Covid-19 di Indonesia. J Communio J Jur Ilmu Komun. 2021; 10(1): 88-106.

[17] Renata CD. Pengaruh Terpaan Postingan Informasi Kesehatan Di Instagram Dan Daya Tarik Pesan Iklan Layanan Masyarakat Di Youtube Terhadap Minat Khalayak Dalam Melakukan Vaksin Covid - 19. MEDIALOG J Ilmu Komun. Mar 2021; 4(1): 48-60.

[18] Nanda SW. Gambaran Tingkat Pengetahuan Tentang Gejala dan Pencegahan COVID-19 di SMA Negeri 2 Plus Panyabungan. Repository Universitas Sumatera Utara. 2021.

[19] Melanie Taye G, Bose L, Beressa T, Tefera G, Mosisa B, Dinsa H et al. CoVID-19 Knowledge, Attitudes, and Prevention Practices among People with Hypertension and Diabetes Mellitus Attending Public Health Facilities in Ambo, Ethiopia. Infection and Drug Resistance. 2020; 13: 4203-4214. 